\title{
太陽光発電と燃料電池の併用発電の有効性に関するライフスタイル別評価 EVALUATION OF THE EFFECTIVENESS OF COMBINED POWER GENERATION USING PHOTOVOLTAIC GENERATION AND SOLID OXIDE FUEL CELLS BASED ON LIFESTYLE
}

\author{
金 ジョンミン*1, 田辺 新一*2 \\ Jungmin KIMand Shin-ichi TANABE
}

\begin{abstract}
Since the Great East Japan Earthquake, although it has been required to introduce renewable energy and save energy in houses, the supply and demand of electric power remains an important issue. This study's purpose is to verify the effectiveness of combined power generation using photovoltaic power generation (PV) and solid oxide fuel cells (SOFCs) by lifestyle. Focusing on understanding the impact of different lifestyles on energy consumption and the equipment capacity and power generation method to achieve a zero energy house (ZEH), we evaluated the equipment introduction effect and economic efficiency in multiple life patterns.
\end{abstract}

Keywords : Photovoltaic power generation, Solid Oxide Fuel Cells (SOFC), Combined power generation, Lifestyle 太陽光発電, 燃料電池, 併用発電, ライフスタイル

\section{1 はじめに}

東日本大震災以降、再生可能エネルギー導入や住宅の省エネルギ 一化が求められているが、現在に至るまで電力需給は依然重要な問 題である。住宅の省エネルギー化の推進に伴い、ネット・ゼロ・エ ネルギーハウス $(\mathrm{ZEH})$ の普及が促進され、住宅への小型分散型エ ネルギーシステムとして住宅用発電設備の導入に対する期待が大き (1)。一方、ZEH の普及に伴い、余剩電力の逆潮流による急激な電 圧上昇が懸念され、アメリカにおけるダックカーブの問題のように 都市全体のエネルギー消費構造にも影響を及ぼすと予想されるため 2)3)、デマンドレスポンス (DR) やバーチャルパワープラント (VPP) による制御により、グリッド全体での電力潮流量の調整やピークの 平準化が求められている。

近年、太陽光発電（以下、PV と呼ぶ）設備による発電が見込めな い時間帯・地域に、他の方法でエネルギー供給する創エネ機器を組 み合わせた「併用発電注1)」が注目されている ${ }^{4)}$ 。併用発電に該当す る創エネ機器は $\mathrm{PV}$ 、燃料電池 (以下、 $\mathrm{FC}$ と呼ぶ)、蓄エネ機器は 蓄電池 (以下、BT と呼ぶ) 、電気自動車などがある。併用発電によ るメリットは以下のように 3 点が挙げられる。

・併用発電することにより、売電量が増加する「押し上げ効果」 が生じる。

・PV 単独発電では日照条件による制約があるが、発電設備を併 用することにより、雨天日や暑天日でも発電することができる。

・FC は停電時に自立運転ができるため、PV と同様に住宅内に電 気を供給することができる。（但し、停電時に発電中であること）
国土技術政策総合研究所より、系統電力とガス給湯器を利用する 従来の住宅と系統電力及び FC、PV、BT、ガス給湯器を利用するス マートハウスの $\mathrm{CO}_{2}$ 削減効果を検証した結果、従来の住宅よりスマ ートハウスの方が $64 \%$ 程度の $\mathrm{CO}_{2}$ 削減効果が期待できることが示 された 5)。大阪ガスは「併用発電」システムを導入した省エネルギ 一住宅を一般公開し、「併用発電」により一次エネルギー消費量が約 $55 \% 、 \mathrm{CO}_{2}$ 排出量が約 $70 \%$ 削減する結果を示している ${ }^{6}$ 。また、PV に個体酸化物系燃料電池（Solid Oxide Fuel Cell : 以下、SOFC と 呼ぶ）を組み合わせた「併用発電」の戸建住宅の販売も行われてい る 7)。

以上のように、「併用発電」システム導入のため、実践的な検討が 行われている。一方、ライフスタイルや世帯構成、生活パターン、 設備機器容量などを考慮した、設備導入コストによる経済性評価に 関する研究は少ない。

\section{2 研究目的}

本研究では、ライフスタイルによる PV と SOFC の併用発電の有 効性検証を目的として、 $\mathrm{SOFC} \cdot \mathrm{PV} ・ \mathrm{BT}$ などの家庭用分散型エネ ルギーシステムのシミュレーションモデルを作成した。ライフスタ イルの違いがエネルギー消費量へ及ぼす影響の把握や ZEH 達成の 核となる設備機器容量、発電方法に着目し、複数の生活パターンに おける設備導入効果および経済性評価を行った。経済性評価におい ては、経済産業省資源エネルギー庁より定義された併用発電の場合 の $\mathrm{ZEH}$ 評価に従って経済性評価を行った ${ }^{8)}$

\footnotetext{
11 早稲田大学理工学術院総合研究所 次席研究員·博士 (工学) Junior Researcher, Dept. of Architecture, Waseda University, Dr.Eng.
}

22 早稲田大学創造理工学部建築学科教授・工博 Prof., Dept. of Architecture, Waseda University, Dr.Eng. 


\section{3 シミュレーションモデル概要}

図 1 にシミュレーション全体フローを示す。本シミュレーション は、数值解析ソフトMATLAB を用いてプログラムの記述を行った。 シミュレーションモデルは既往研究 9)1011)をもとに、温変動計算モ デル、エアコン（以下、 $\mathrm{AC}$ と呼ぶ） モデル、 $\mathrm{PV}$ モデル、ヒートポ ンプ給湯器（以下、 $\mathrm{EC}$ と呼ぶ）モデル、 $\mathrm{BT}$ モデルを作成し、既往 研究 ${ }^{12)}$ を参考に、SOFC 発電モデル、SOFC 給湯モデルを新たに追 加した。地域条件 (気象条件) - 建物条件 - 居住者条件を入力条件之 し、住宅の電力消費量と発電量の算出と余剩電力の有無の判定をし た。余剩電力がある場合は、運用条件ごとに発電電力の自家消費に 活用し、室温 $\cdot \mathrm{PV} \cdot \mathrm{SOFC}$ 発電量. 売買電力量. BT 充放電量・ カ ス消費量を計算した。

\section{1 対象住宅概要}

表 1 に対象住宅概要、表 2 に各部材構成および性能值、表 3 に設 備機器仕様を示す。対象住宅は鉄骨構造の地上 1 階建ての高断熱住 宅である。全開口部の断熱ブラインドを閉じた状態で Q 值は 1.9 $\mathrm{W} /\left(\mathrm{m}^{2}\right.$ ・ K $)$ である。外壁および床は断熱材の内側に ALC が配置さ れ、蓄熱性が高い。設備機器においては、PV と、SOFC、リチウム イオン BT、 EC、AC、換気設備を備えた。 PV パネルは、単結晶セ ルの太陽電池を用い、最大出力は $4.6 \mathrm{~kW}$ 、発電効率は $16.6 \%$ であ。 SOFC は、定格発電出力 $700 \mathrm{~W}$ 、発電効率 $42 \%$ (高位発熱量基準)、 排熱回収効率 $39.2 \%$ （高位発熱量基準、 $0^{\circ} \mathrm{C} 、 1$ 気圧時）である。 BT 設備は、定格容量 $7.2 \mathrm{kWh}$ 、放電深度 $80 \%$ 、充電効率 $90 \%$ 、放 電効率 $94 \%$ である。 EC は、高性能 $\mathrm{CO}_{2}$ ヒートポンプ給湯器で、貯 湯タンクの容量は $370 \mathrm{~L}$ 、加熱能力は $4.5 \mathrm{~kW}$ である。 $\mathrm{AC}$ は、冷房 能力 $3.6 \mathrm{~kW}$ 、暖房能力 $4.2 \mathrm{~kW}$ の空冷式の高性能ヒートポンプ $\mathrm{AC}$ を利用した。換気は、全熱交換器 0.5 回/ h で 24 時間稼働させた。

\section{2 設備モデル概要}

表 4 に設備モデル入出力条件一覧を示す。創エネルギー設備・蓄 エネルギー設備・空調設備・給湯設備の設備モデルを作成し、動作 条件を入力值として PV と SOFC の併用発電運用を再現した。本モ デルは熱容量質点系のモデルであり、対象建物について、経緯度、 解析期間、解析期間中の外気温 - 太陽高度 -太陽方位角 - 全天日射量 および内部発熱量を入力することで、室温が算出される。また、あ る条件下での COP および電力消費量を算出するために、室内温度 ・ 室内相対湿度 - 外気温 - 外気相対湿度を入力条件とし、逆力ルノー サイクルによって算出した理論効率と実効率の比率を推定し熱源特 性や泠媒物性がわからない $\mathrm{AC}$ においても COP および電力消費量 を算出する。

\subsection{SOFC モデル}

本研究で扱った SOFC システムは 2014 年発売されたもので、現 在発売中のものより発電効率や排熱回收効率が低い可能性がある。

図 2 にSOFC モデル概要、図 3 に実測值とシミュレーション值の SOFC ガス消費量比較結果を示す。対象機器仕様は、発電効率を $42 \%$ 、 排熱回収効率を $39.2 \%$ 、給湯用貯湯タンク容量を $90 \mathrm{~L}$ 、補助ボイラ 一効率を $95 \%$ とする。電力消費量・給湯負荷を入力值とし、発電量 . SOFC のガス流量・補助ボイラーのガス流量を算出する。対象建物 における 2014 年度の SOFC 夏季実測結果（9/25）と比較した。経時 変化では、発電量に関しては、エアコン稼動の影響で宅内消費電力 がハンチングする際に、実測発電量よりモデル発電量の方が多くな

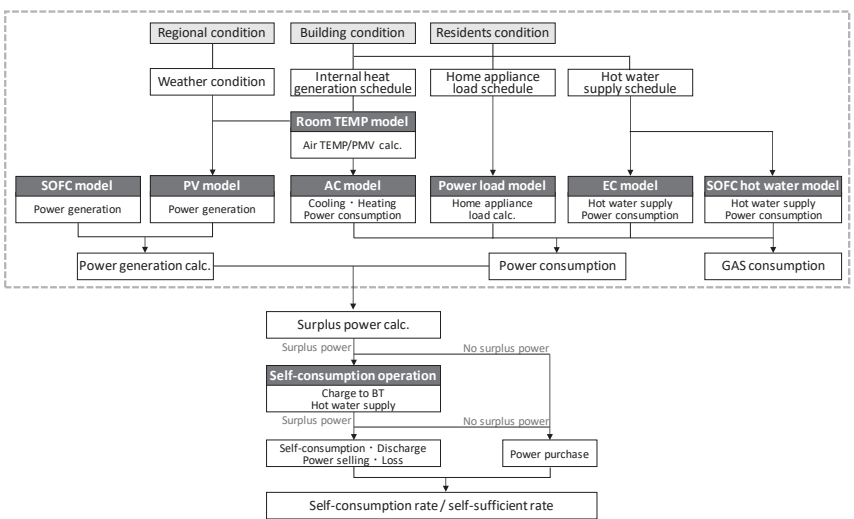

Fig.1 Overall simulation flow

Table 1 Building outline

\begin{tabular}{|c|c|c|c|c|}
\hline Location & Shizuoka, Japan & \multicolumn{2}{|c|}{ Total floor area } & $53.6 \mathrm{~m}^{2}$ \\
\hline Number of floor & 1 & \multicolumn{2}{|c|}{ Max height } & $5.3 \mathrm{~m}$ \\
\hline Main structure & Steel & \multicolumn{2}{|c|}{ Ceiling height } & $2.7 \mathrm{~m}$ \\
\hline Thermal transmittance (UA) & $0.29 \mathrm{~W} /\left(\mathrm{m}^{2} \cdot \mathrm{K}\right)$ & Solar heat gai & rate $(n A)$ & 0.6 \\
\hline Floor plan (non-scale) & \multicolumn{2}{|c|}{ Outer wall diagram } & \multicolumn{2}{|c|}{ diagram } \\
\hline 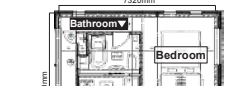 & in & $\begin{array}{l}T \\
\text { Ct100 } \\
\text { layer }\end{array}$ & & mat t12 \\
\hline & & & & \\
\hline 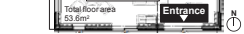 & & el plate 16 type & & 等, \\
\hline
\end{tabular}

Table 2 Material property value of building each part

\begin{tabular}{|c|c|c|c|c|c|}
\hline & Constitution & $\begin{array}{r}\text { Thickne } \\
{[\mathrm{mm}]} \\
\end{array}$ & $\begin{array}{c}\text { Thermal } \\
\text { conductivity } \\
{[\mathrm{W} / \mathrm{m} \cdot \mathrm{K}]}\end{array}$ & $\begin{array}{c}\text { Thermal } \\
\text { transmittance } \\
\left.\mathrm{rW} /\left(\mathrm{m}^{2} \cdot \mathrm{K}\right)\right]\end{array}$ & $\begin{array}{c}\text { Solar heat } \\
\text { acquisition rate } \\
{\left[\mathrm{W} /\left(\mathrm{m}^{2} \cdot \mathrm{K}\right)\right]}\end{array}$ \\
\hline \multirow{5}{*}{$\begin{array}{l}\text { Outer } \\
\text { wall }\end{array}$} & & 100 & 0.19 & \multirow{5}{*}{ - } & \multirow{5}{*}{ 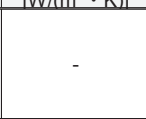 } \\
\hline & ayer & & & & \\
\hline & nolic foam & 100 & 0.02 & & \\
\hline & tight sheet & & - & & \\
\hline & el plate 16type & - & - & & \\
\hline \multirow{5}{*}{$\begin{array}{l}\text { Inner } \\
\text { wall }\end{array}$} & & 50 & 0.19 & \multirow{5}{*}{1.04} & \multirow{5}{*}{ - } \\
\hline & wood & 5 & 0.16 & & \\
\hline & layer & & & & \\
\hline & wood & 5 & 0.16 & & \\
\hline & & 50 & 0.19 & & \\
\hline \multirow{5}{*}{$\begin{array}{l}\text { Ceiling } \\
\text { roof }\end{array}$} & ster board & 9 & 0.22 & \multirow{5}{*}{0.2} & \multirow{5}{*}{-} \\
\hline & layer & & & & \\
\hline & & 75 & 0.19 & & \\
\hline & nolic foam & 100 & 0.02 & & \\
\hline & lation sheet waterproof & & & & \\
\hline \multirow{5}{*}{ Floor } & ring & 15 & 0.16 & \multirow{5}{*}{0.2} & \multirow{5}{*}{-} \\
\hline & water mat & 12 & - & & \\
\hline & wood & 18 & 0.16 & & \\
\hline & & 100 & 0.19 & & \\
\hline & nolic foam & 100 & 0.02 & & \\
\hline \multirow{2}{*}{ Window } & minum sash & - & & \multirow{2}{*}{1.3} & \multirow{2}{*}{0.33} \\
\hline & shield Low-E pair & - & 1.15 & & \\
\hline \multirow{2}{*}{\begin{tabular}{l|l}
\multirow{2}{*}{ Blind } & $\mathrm{S}$ \\
\cline { 2 - 2 } & $\mathrm{In}$ \\
\end{tabular}} & ar shading blind & - & - & 6.4 & \multirow[t]{2}{*}{-} \\
\hline & Ilation blind & & - & 2.6 & \\
\hline \multicolumn{6}{|c|}{ Table 3 Equipment specification } \\
\hline \multirow{5}{*}{ PV } & \multirow{2}{*}{\multicolumn{2}{|c|}{ Maximum power output }} & \multicolumn{3}{|c|}{$4.6 \mathrm{~kW}$} \\
\hline & \multirow{2}{*}{\multicolumn{2}{|c|}{$\begin{array}{c}\text { Generation efficiency } \\
\text { Direction } \cdot \text { Angle }\end{array}$}} & \multicolumn{3}{|c|}{$16.61 \%$} \\
\hline & & & & South, $10^{\circ}$ & \\
\hline & Temperature loss coe & ficient & 0.43 & $\%$ (standard of 2 & $\left.25^{\circ} \mathrm{C}\right)$ \\
\hline & Other loss & & & $12.5 \%$ & \\
\hline & Rated power & & & $0.70 \mathrm{~kW}$ & \\
\hline & Rated heat & & & $0.65 \mathrm{~kW}$ & \\
\hline & Generation efficien & & $42 \%($ & Higher Heating & Value) \\
\hline SOFC & Waste heat recovery ef & ficiency & $39.2 \%$ & (Higher Heating & Value) \\
\hline & Hot water storage $\mathrm{t}$ & & & $90 \mathrm{~L}$ & \\
\hline & Backup boiler efficie & ncy & & $95 \%$ & \\
\hline & Charge-Discharge effi & iency & Charge & $80 \%$ / Dischar & ge $94 \%$ \\
\hline $\mathrm{BI}$ & Rated output & & & $2.5 \mathrm{~kW}$ & \\
\hline & Heating capacit) & & & $4.5 \mathrm{~kW}$ & \\
\hline EC & Thermal transmitta & & & $1.018 \mathrm{~W} /\left(\mathrm{m}^{2} \cdot \mathrm{K}\right)$ & \\
\hline (heat pump & Rated COP & & Summer 5.3 & Mid season 4 . & $6 /$ Winter 3.0 \\
\hline & Tank temperatur & & Summer $65^{\circ} \mathrm{C}$ & I Mid season al & nd Winter $90^{\circ} \mathrm{C}$ \\
\hline & Capacity & & cooling 3 & $.6 \mathrm{~kW}^{*} /$ heating & $4.2 \mathrm{~kW}^{* *}$ \\
\hline AC & Power consumpti & & & $0.825 \mathrm{~kW}$ & \\
\hline & $\mathrm{COP}$ & & coolin & ng 4.36 / heating & 5.09 \\
\hline & Ventilation & & Total enthal & py heat exchan & ger $120 \mathrm{~m}^{3} / \mathrm{h}$ \\
\hline
\end{tabular}

*: outdoor air temperature $35^{\circ} \mathrm{C}$, indoor air temeprature $27^{\circ} \mathrm{C}$
$* *$ : outdoor air temperature $7^{\circ} \mathrm{C}$, indoor air temeprature $20^{\circ} \mathrm{C}$

つた。1 日積算值では、シミュレーション值は発電量、ガス消費量 それぞれ実測值の $105 \%$ 、98 \%となり、妥当性が確かめられた。

\section{4 シミュレーション条件}

表 5 にシミュレーション条件を示す。延床面積は世帯構成に応じ て定め、地域と延床面積以外は「対象住宅」と同様に設定した。地 
域 1 条件・PV 容量 4 条件・給湯 2 条件・ BT 容量 1 条件・世帯構成 6 条件を組み合わせた計 48 条件について計算し、解析を行った。 BT については、PV 発電の余剩電力がある場合のみ充電し、買電に よる充電は行わないものとした。

表 6 にライフスタイル別電力需要条件、表 7 にライフスタイル別 給湯需要条件を示寸。生活パターンは、世帯構成 2 パターン、世帯 人員属性が 2 パターンの計 4 パターンとした。既往研究 13)141415) およ び「SCHEDULE」注2)を参考に、内部発熱スケジュール、家電機器 の電力消費スケジュール、給湯負荷スケジュールを夏季・中間期・ 冬季について設定した。家電機器の電力消費の設定および給湯需要 に関しては、既往研究 16)1711819)を参考にした。空調の設定温度は $25^{\circ} \mathrm{C}$ 、稼働時間は睡眠時間以外の在宅時間のみと設定し、ライフス タイル別給湯需要は使用温度換算量である。EC 貯湯タンクは世帯 ごとの給湯需要を考慮し、2 人世帯は $185 \mathrm{~L} 、 4$ 人世帯は $370 \mathrm{~L}$ とし た。中間期と冬季は、朝・昼においても給湯需要があり、朝方にタ ンク蓄熱量が一定值を下回った場合は炊きましを行う設定とした。 冬季は外気温が低くなることや日射量が少ないことにより HP 給湯 器の効率が低下し、給湯の炊き上げ時間が長くなるため、沸き上げ 開始時間を 10 時 30 分と設定した ${ }^{20)}$

\section{4 シミュレーション結果}

\section{1 二人世帯のライフスタイルによる評価}

図 4 に 2 人世帯の日積算エネルギー消費（年間平均值）を示す。 売買電力量に関して、PV のみによる単独発電では PV 容量の増加 に伴い、売電量は増加し買電量は減少した。PV と SOFCによる併 用発電では PV 容量の増加に伴い、PV からの売電量は増加したが、 買電量はSOFC の発電で賄う為に発生しなかった。また、SOFC か らの売電量はライフスタイルにより約 $2.0 \sim 4.0 \mathrm{kWh}$ の差があった が、PV 容量による差異はなかった。単独発電の場合、売電量が買電 量より大きくなる条件は、片働きの多消費型は PV7.5kW、片働きの 普通型は PV4.6kW 以上、片働きの節約型は PV $3.0 \mathrm{~kW}$ 以上、共働 きの普通型は PV4.6kW 以上であった。

PV から宅内一の電力消費量は単独発電と併用発電の両条件とも に、PV 容量の増加に伴い増加した。BT の充放電量に関して、単独 発電では PV 容量の増加に伴い BT の充放電量が増加した。一方、 併用発電ではライフスタイルによる BT 充放電量の差があったが、 PV 容量による差異は小さかった。また、片働きの節約型以外の条 件では、深夜の時間帯にかけて SOFC から BT への充電量が約 1.9 〜 $3.2 \mathrm{kWh}$ 程度あった。一方、片働きの節約型の条件は BT 充放電 量が発生しなかったことから、片働きの節約型は併用発電を利用す る場合、BT の導入は不要なことが示された。

自家消費率注 3)に関して、単独発電では 19～59\%となった。全条 件において PV $3.0 \mathrm{~kW}$ 条件で自家消費率が最も高い結果となり、PV 容量の増加に伴い自家消費率は低下寸る傾向がみられた。一方、併 用発電では自家消費率が $30 \%$ 以下にとどまり、全体的に低い結果と なった。PV 容量の増加に伴い自家消費率は低下したが、大きな差 はみられなかった。また、片働きの節約型の自家消費率は $10 \%$ 未満 であり、併用発電が不要である可能性が示された。

\section{2 四人世帯のライフスタイルによる評価}

図 5 に 4 人世帯の日積算エネルギー消費量(年間平均值)を示す。
Table 4 Simulation model input and output condition

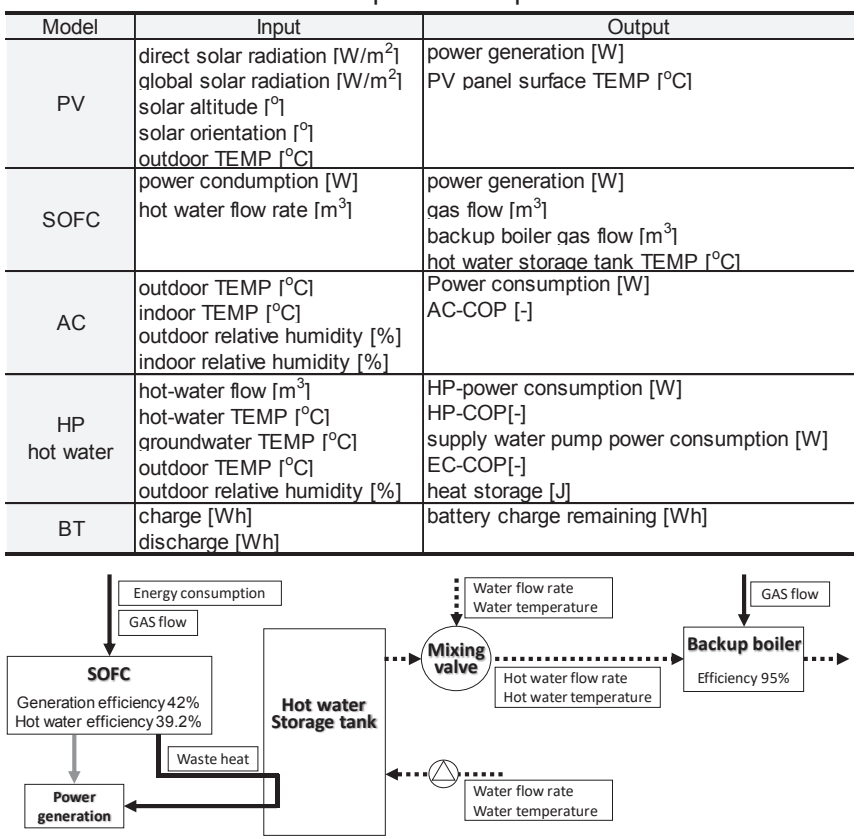

Fig.2 Structure of SOFC model

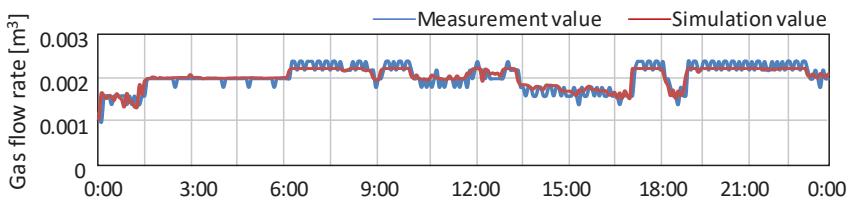

Fig.3 Comparison of measurement value and simulation value of SOFC gas flow rate

Table 5 Outline of simulation condition

\begin{tabular}{|c|c|c|c|c|}
\hline \multirow{5}{*}{$\begin{array}{l}\text { Building } \\
\text { structure }\end{array}$} & Location & \multicolumn{3}{|c|}{ Chiyoda-ku, Tokyo } \\
\hline & \multirow[t]{2}{*}{ Total floor area } & \multicolumn{3}{|c|}{ 2-person household $55 \mathrm{~m}^{2}$} \\
\hline & & \multicolumn{3}{|c|}{ 4-person household $110 \mathrm{~m}^{2}$} \\
\hline & Number of floors & \multicolumn{3}{|c|}{1} \\
\hline & $Q$ value & \multicolumn{3}{|c|}{$1.9 \mathrm{~W} /\left(\mathrm{m}^{2} \cdot \mathrm{K}\right)$} \\
\hline \multirow{8}{*}{$\begin{array}{l}\text { Equipment } \\
\text { condition }\end{array}$} & SOFC & \multicolumn{3}{|c|}{ Rated operation $0.7 \mathrm{~kW}$} \\
\hline & \multirow{2}{*}{ PV capacity } & \multicolumn{3}{|c|}{$3.0 \mathrm{~kW}, 4.6 \mathrm{~kW}, 6.0 \mathrm{~kW}, 7.5 \mathrm{~kW}$} \\
\hline & & \multicolumn{3}{|c|}{ (setting direction: south $5^{\circ}$ ) } \\
\hline & BT capacity & \multicolumn{3}{|c|}{$7.2 \mathrm{kWh}$} \\
\hline & Water heater & \multicolumn{3}{|c|}{ SOFC, EcoCute (daytime mode) } \\
\hline & \multirow{3}{*}{$\begin{array}{l}\text { Water heater tank } \\
\text { capacity }\end{array}$} & SOFC & \multicolumn{2}{|c|}{$90 \mathrm{~L}$} \\
\hline & & \multirow{2}{*}{ EcoCute } & \multirow{2}{*}{\multicolumn{2}{|c|}{$\begin{array}{l}\text { 2-person household } 185 \mathrm{~L} \\
\text { 4-person household } 370 \mathrm{~L}\end{array}$}} \\
\hline & & & & \\
\hline \multirow{5}{*}{ Lifestyle } & & Multi & Normal & Saving \\
\hline & $\begin{array}{l}\text { 2-person household } \\
\text { (one income) }\end{array}$ & $\mathrm{O}$ & $\mathrm{O}$ & $\mathrm{O}$ \\
\hline & $\begin{array}{c}\text { 2-person household } \\
\text { (two income) }\end{array}$ & & $\mathrm{O}$ & \\
\hline & $\begin{array}{l}\text { 4-person household } \\
\text { (one income) }\end{array}$ & & $\bigcirc$ & \\
\hline & $\begin{array}{c}\text { 4-person household } \\
\text { (two income) }\end{array}$ & & $\bigcirc$ & \\
\hline
\end{tabular}

Table 6 Condition of energy demand in each lifestyle

\begin{tabular}{|c|c|c|c|c|}
\hline & Multi & Normal & Saving \\
\hline \multirow{2}{*}{$\begin{array}{c}\text { Air } \\
\text { conditioning }\end{array}$} & Setting temperature & $25^{\circ} \mathrm{C}$ & $25^{\circ} \mathrm{C}$ & $25^{\circ} \mathrm{C}$ \\
\hline & Operating time & \multicolumn{3}{|c|}{ Only in the housing (except sleeping) } \\
\hline \multirow{4}{*}{$\begin{array}{l}\text { Hot water } \\
\text { [L/15min] }\end{array}$} & Face wash & 14 & 14 & 14 \\
\hline & Bath & 20 & 20 & 20 \\
\hline & Shower & - & - & 35 \\
\hline & Cook & 14.5 & 14.5 & 14.5 \\
\hline
\end{tabular}

*: Normal conditions of 2-person household and 4-person household are the same

Table 7 Condition of hot water demand in each lifestyle Unit: L/d

\begin{tabular}{|c|c|c|c|c|c|c|c|}
\hline & \multicolumn{2}{|c|}{ Summer } & \multicolumn{2}{|c|}{ Spring and Autumn } & \multicolumn{2}{|c|}{ Winter } \\
\hline & & weekday & weekend & weekday & weekend & weekday & weekend \\
\hline \multirow{3}{*}{$\begin{array}{l}\text { 2-person } \\
\text { household* }^{*}\end{array}$} & Multi & 320 & 320 & 364 & 364 & 421 & 481 \\
\hline & Normal & 240 & 240 & 324 & 324 & 351 & 351 \\
\hline & Saving & 180 & 180 & 184 & 184 & 211 & 211 \\
\hline \multirow{2}{*}{$\begin{array}{l}\text { 4-person } \\
\text { household }\end{array}$} & One income & \multicolumn{2}{|c|}{421} & \multicolumn{2}{|c|}{435} & \multicolumn{2}{|c|}{427} \\
\hline & Two income & \multicolumn{2}{|c|}{420} & \multicolumn{2}{|c|}{422} & \multicolumn{2}{|c|}{425} \\
\hline
\end{tabular}

*: Normal conditions of one income and two income are the same

売買電力量に関して、単独発電では PV 容量の増加に伴い、PVから の売電量は増加し、買電量は減少した。併用発電では PV 容量の増 


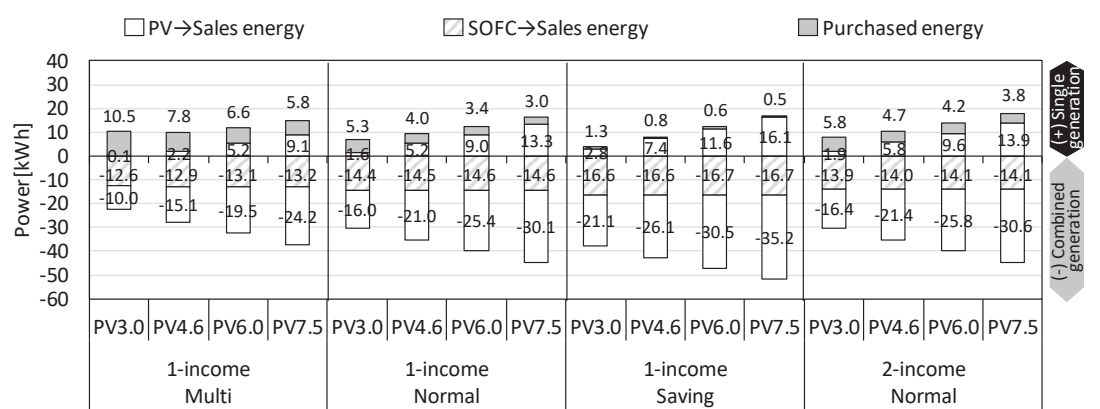

(a) Total trading power

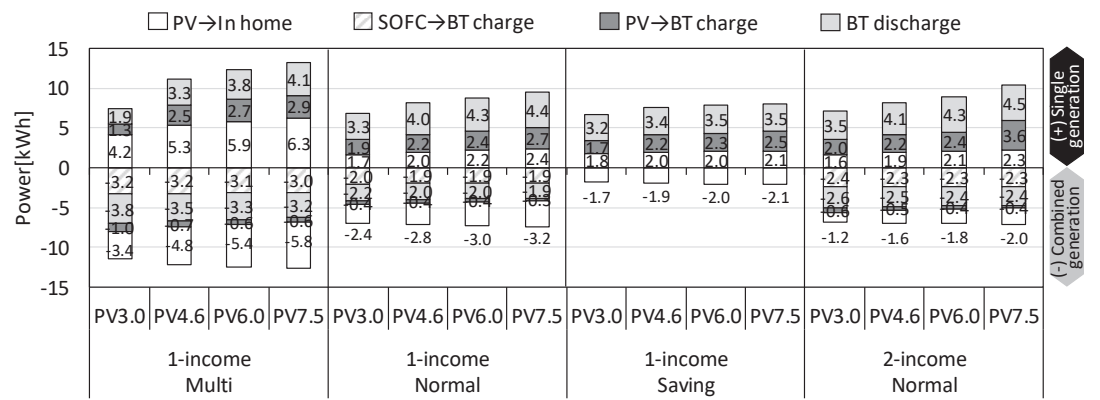

(b) BT charge $\cdot$ discharge

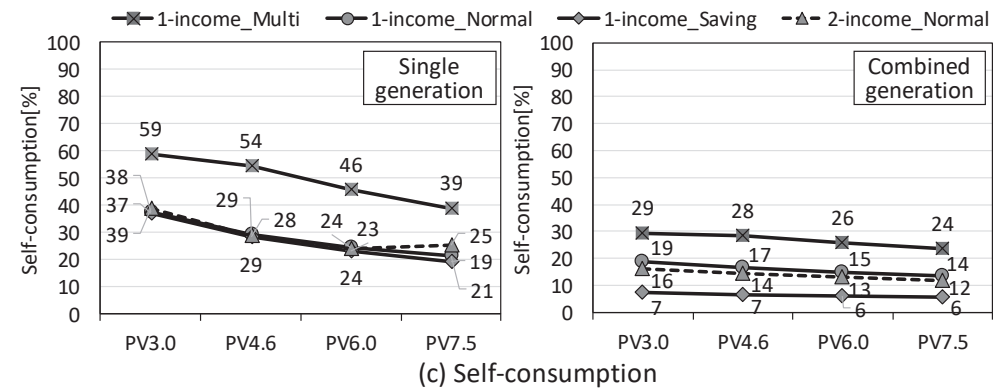

Fig.4 Daily total energy consumption for 2-person household (annual average)

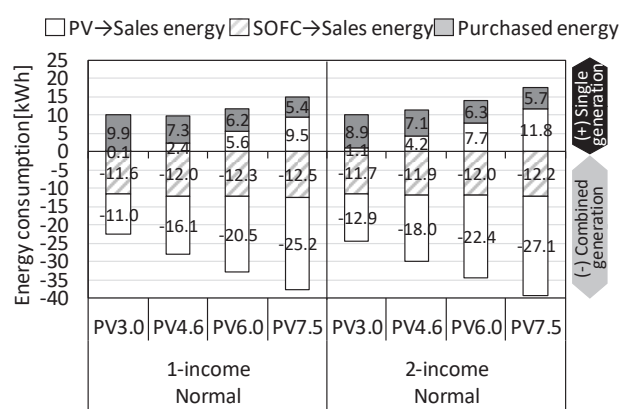

(a) Total trading power

$\square \mathrm{PV} \rightarrow$ In home $\square$ SOFC $\rightarrow$ BT charge $\square \mathrm{PV} \rightarrow \mathrm{BT}$ charge $\square$ BT discharge

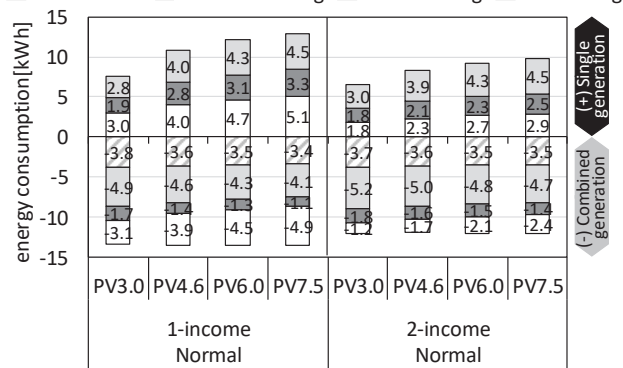

(b) BT charge $\cdot$ discharge

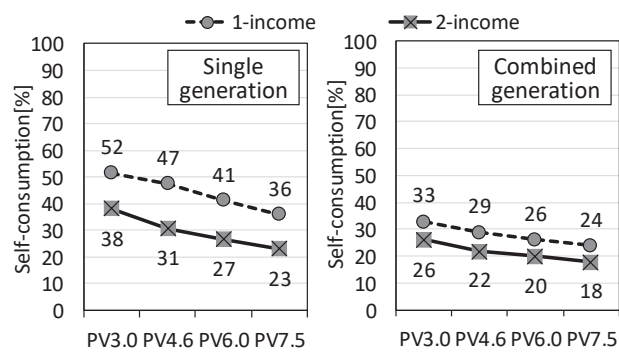

(c) Self-consumption

Fig.5 Daily total energy consumption for 4person household (annual average)
加に伴い、PV からの売電量は増加したが、買電量は発生しなかっ た。また、全条件において SOFC からの売電量は約 $12.0 \mathrm{kWh}$ 程度 で大きな差はなかった。単独発電の場合、売電量が買電量より大き くなる条件は、片働きの普通型は PV7.5kW、共㗢きの普通型は PV6.0kW 以上であった。

PV から宅内一の電力消費量は単独発電と併用発電の両条件とも に、 $\mathrm{PV}$ 容量の増加に伴い増加した。BT の充放電量に関して、単独 発電では PV 容量の増加に伴い BT の充放電量が増加した。一方、 併用発電では PV 容量の増加に伴い BT の充放電量はやや減少した が、大きな差異はなかった。また、併用発電の場合は深夜の時間帯 にかけて SOFC から BT への充電量が約 $3.6 \mathrm{kWh}$ あった。

自家消費率は、単独発電で 23～52\%、併用発電で 18～33\%とな り、全条件において PV 容量の増加に伴い自家消費率は減少した。 また、併用発電より単独発電の方が自家消費率が高い結果となった。

\section{3 一次エネルギー消費率と ZEH 達成率の評価}

図 6 に一次エネルギー削減率注 4) と ZEH 達成率注5)を示す。 2 人世 帯の一次エネルギー消費量に関して、単独発電では、片働きの多消 費型が $27.5 \mathrm{GJ} /$ 年、片働きの普通型が $18.7 \mathrm{GJ} /$ 年、片働きの節約型 が $11.2 \mathrm{GJ} /$ 年、共働きの普通型が $18.2 \mathrm{GJ} /$ 年であった。併用発電で は、片働きの多消費型が $30.4 \mathrm{GJ} /$ 年、片働きの普通型が $21.9 \mathrm{GJ} /$ 年、 片働きの節約型が $13.9 \mathrm{GJ} /$ 年、共働きの普通型が $21.2 \mathrm{GJ} /$ 年であっ た。併用発電の場合は、ガス消費量と補助ボイラーの利用によるエ
ネルギー消費があるため、各条件の一次エネルギー消費量が単独発 電より併用発電の方が約 $3.0 \mathrm{GJ} /$ 年高くなった。ZEH 達成率に関し て、単独発電と併用発電の両条件ともに、PV 容量の増加に伴い ZEH 達成率も増加した。単独発電において片働きの多消費型はPV7.5kW、 片働きの普通型は PV4.6kW 以上、片働きの節約型は PV3.0kW 以 上、共働きの普通型は PV4.6kW 以上の条件で ZEH 達成率が $100 \%$ 以上となった。併用発電においては全ての条件で ZEH 達成率が 150 〜 627\%で高い結果となった。

4 人世帯の一次エネルギー消費量に関して、単独発電では片働き の普通型が $27.5 \mathrm{GJ} /$ 年、共㗢きの普通型が $25.6 \mathrm{GJ} /$ 年であり、併用 発電では片働きの普通型が $27.5 \mathrm{GJ} /$ 年、共働きの普通型が $25.6 \mathrm{GJ} /$ 年であった。 4 人世帯の場合は、併用発電のガスと補助ボイラーに よるエネルギー消費量と EC によるエネルギー消費量が同様の值と なり、一次エネルギー消費量の差はみられなかった。ZEH 達成率に 関して、単独発電と併用発電の両条件共に、PV 容量の増加に伴い ZEH 達成率も増加した。単独発電において、片働きの普通型と共働 きの普通型の両方共に、PV7.5kW の条件で ZEH 達成率が 100\%以 上となった。併用発電においてはすべての条件で ZEH 達成率が 148 〜266\%で高い結果となった。

一次エネルギー削減率については単独発電と併用発電の両条件と もに PV 容量の増加に伴い一次エネルギー削減率も増加した。平均 一次エネルギー削減量は単独発電で $17 \%$ 、併用発電（PV の余剩電 


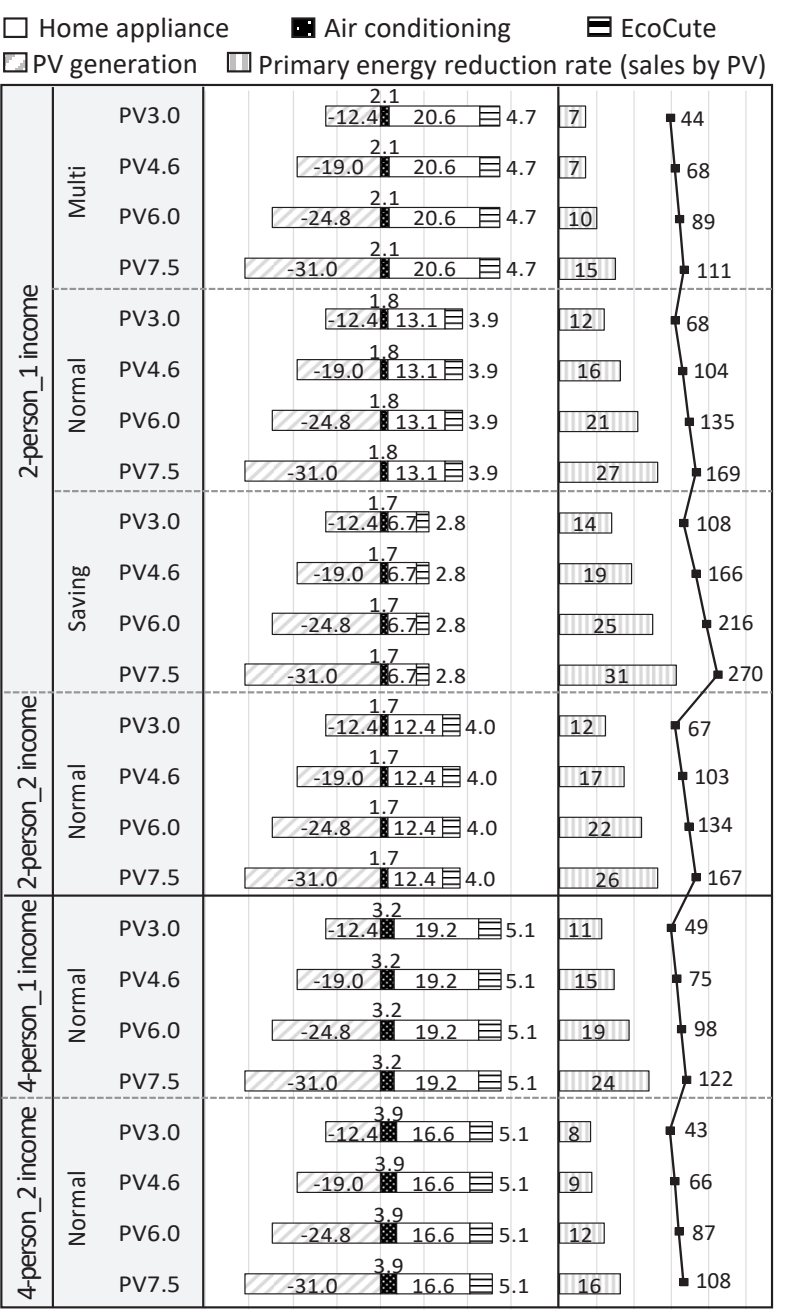

$-40-30-20-100 \begin{gathered}10 \\ \text { Primary energy }\end{gathered} 2030 \quad 0 \quad 1020304050$
Primary energy supply [GJ/year]

(a) Single generation $\square$ GAS for SOFC $\quad$ GAS for backup boiler $\quad$ SOFC generation

$\square$ Primary energy reduction rate (sales by PV+SOFC) $\quad$ ZEH achievement ratio

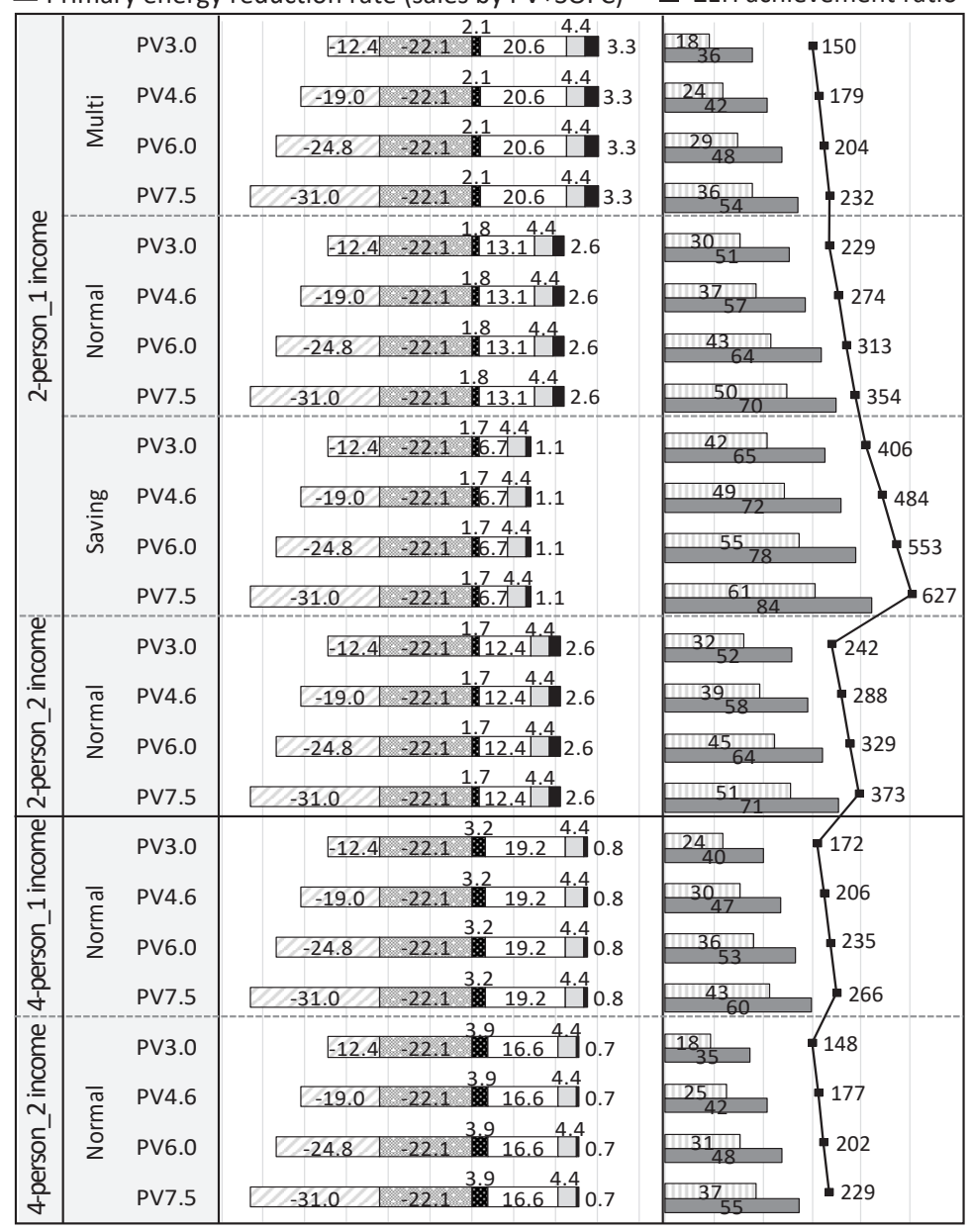

$\begin{array}{llllllllllll}-60-50-40-30-20-10 & 0 & 10 & 20 & 30 & 400 & 20 & 40 & 60 & 80 & 100\end{array}$ Primary energy
supply [GJ/year]

(b) Combined generation

Fig.6 Primary energy reduction rate and ZEH achievement ratio

力のみ売る条件) で $37 \%$ 、併用発電 (PV と $\mathrm{SOFC}$ の余剩電量を売 売る条件）で $56 \%$ となった。併用発電の場合は PVの余剩電力のみ を売る条件に比べ、PV と SOFC の余剩電力を売る条件の方が、一 次エネルギー削減率が平均 19\%増加することが確認できた。

以上より、自家消費率や ZEH 達成率、売買電力量などを考慮 し、ライフスタイルと発電方法による設備機器容量を表 8 に提案 した。以下の項目を満たす設備機器容量を示した。

\section{・ZEH 達成率が $100 \%$ 以上とな}

・自家消費率が最も高くなる

・売電量と買電量が同様、または売電量が買電量を上回る

併用発電は、全てのライフスタイルにおいてPV3.0kW と SOFC、 BT7.2kWh を併用することにより、買電なしで過ごせることが確認 できた。一方、単独発電では、ライフスタイルによって必要な PV 発 電量を上回る。なお、2019 年以降 FIT が順次終了寸ることにより、 PV 発電の余剩電力の買取価格の下落が予想され、提案した設備機 器容量では買電による支出を売電による収入で賄うことができない 場合も考えられる。
Table 8 Equipment capacity by lifestyle and power generation

\begin{tabular}{|c|c|c|c|c|c|c|}
\hline & ifestyle & & Power generation & $\mathrm{PV}[\mathrm{kW}]$ & SOFC & $\mathrm{BT}[\mathrm{kWh}]$ \\
\hline \multirow{8}{*}{$\begin{array}{l}\text { 2-persons } \\
\text { household }\end{array}$} & \multirow{6}{*}{$\begin{array}{c}\text { One } \\
\text { income }\end{array}$} & \multirow{2}{*}{ Multi } & Single & 7.5 & - & \multirow{8}{*}{7.2} \\
\hline & & & Combined & 3 & 0.7 & \\
\hline & & \multirow{2}{*}{ Normal } & Single & 6 & - & \\
\hline & & & Combined & 3 & 0.7 & \\
\hline & & \multirow{2}{*}{ Saving } & Single & 3 & - & \\
\hline & & & Combined & 3 & 0.7 & \\
\hline & \multirow{2}{*}{$\begin{array}{c}\text { Two } \\
\text { income }\end{array}$} & \multirow{2}{*}{ Normal } & Single & 4.6 & - & \\
\hline & & & Combined & 3 & 0.7 & \\
\hline \multirow{4}{*}{$\begin{array}{l}\text { 4-persons } \\
\text { househole }\end{array}$} & \multirow{2}{*}{$\begin{array}{c}\text { One } \\
\text { income }\end{array}$} & \multirow{2}{*}{ Normal } & Single & 7.5 & - & \multirow{4}{*}{7.2} \\
\hline & & & Combined & 3 & 0.7 & \\
\hline & \multirow{2}{*}{$\begin{array}{c}\text { Two } \\
\text { income }\end{array}$} & \multirow{2}{*}{ Normal } & Single & 7.5 & - & \\
\hline & & & Combined & 3 & 0.7 & \\
\hline
\end{tabular}

Table 9 Equipment introduction cost

\begin{tabular}{|c|c|c|c|c|c|c|}
\hline & Capacity & $\begin{array}{c}\text { Introduction cost } \\
{\left[\times 10^{4} \text { yen }\right]}\end{array}$ & $\begin{array}{c}\text { Others } \\
10^{4} \text { yen] }\end{array}$ & $\begin{array}{l}\text { Subsidy } \\
{\left[\times 10^{4} \text { yen] }\right.}\end{array}$ & $\begin{array}{c}\text { Service life } \\
\text { [year] }\end{array}$ & $\begin{array}{c}\text { Cost per year } \\
{\left[\times 10^{4} \text { yen }\right]}\end{array}$ \\
\hline \multirow{4}{*}{ PV } & $3.0 \mathrm{~kW}$ & 156 & 64.8 & 115 & 20 & 5.3 \\
\hline & $4.6 \mathrm{~kW}$ & 239 & 75.8 & 115 & 20 & 10.0 \\
\hline & $6.0 \mathrm{~kW}$ & 312 & 96.5 & 115 & 20 & 14.7 \\
\hline & $7.5 \mathrm{~kW}$ & 390 & 106.9 & 115 & 20 & 19.1 \\
\hline BT & $7.2 \mathrm{kWh}$ & 144 & 30.0 & 14.4 & 10 & 16.0 \\
\hline \multirow{2}{*}{ EC } & $370 \mathrm{~L}$ & 29 & - & - & 15 & 1.9 \\
\hline & $180 \mathrm{~L}$ & 25 & - & - & 15 & 1.7 \\
\hline \multirow{2}{*}{$\begin{array}{c}\text { SOFC } \\
\text { (water tank) }\end{array}$} & $0.7 \mathrm{~kW}$ & \multirow{2}{*}{100} & - & - & \multirow{2}{*}{10} & \multirow{2}{*}{10.0} \\
\hline & $90 \mathrm{~L}$ & & - & - & & \\
\hline Backup boiler & $370 \mathrm{~L}$ & 30 & - & - & 15 & 2.0 \\
\hline
\end{tabular}

Table 10 Electricity and gas prices

\begin{tabular}{c|c|c|c}
\hline $\begin{array}{c}\text { Sales energy by PV } \\
\text { [yen/kW] }\end{array}$ & $\begin{array}{c}\text { Sales energy by SOFC } \\
{[\text { yen } / \mathrm{kW}]}\end{array}$ & $\begin{array}{c}\text { Purchase electricity } \\
{[\text { yen } / \mathrm{kW}]}\end{array}$ & $\begin{array}{c}\text { Purchase gas } \\
{\left[\mathrm{yen} / \mathrm{m}^{3}\right]}\end{array}$ \\
\hline 8.5 & 24 & 24 & 106.3 \\
\hline
\end{tabular}




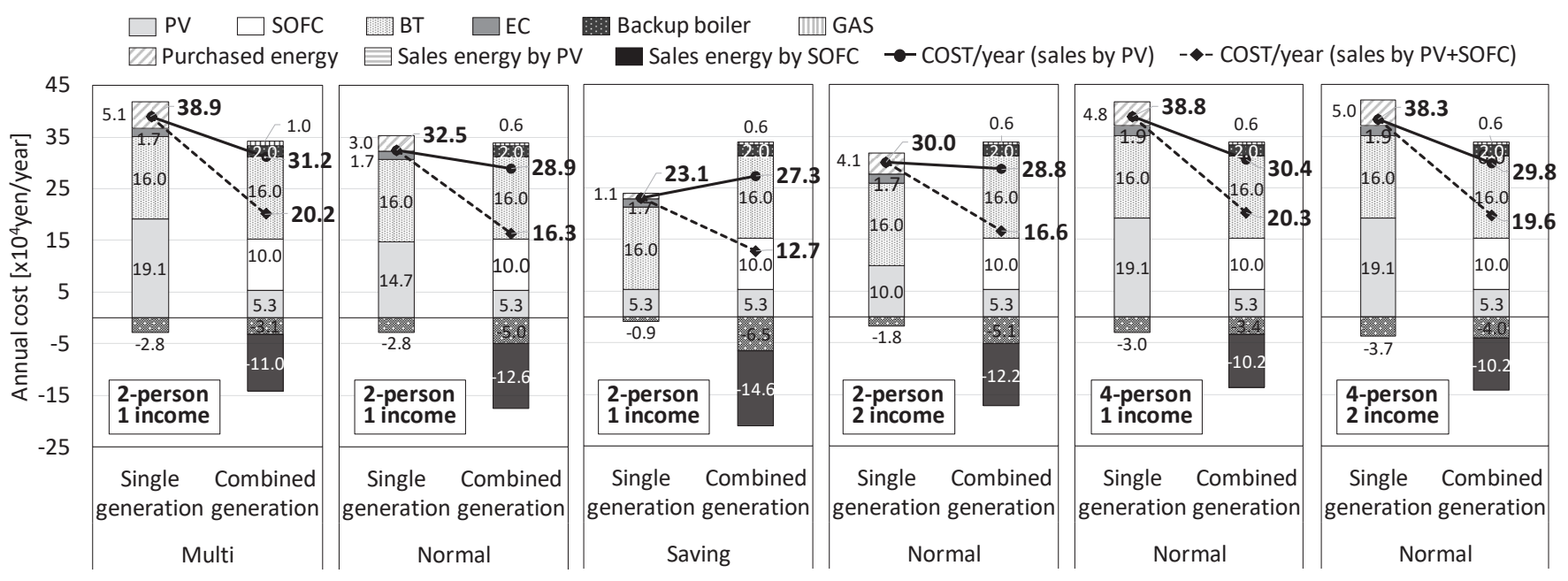

Fig.7 Annual cost by lifestyle and power generation method

\section{4 経済性評価}

表 9 に設備機器の導入コスト、表 10 に電力とガスのコストを示 す。ライフスタイルと発電方法による設備機器容量を提案した表 8 に基づいて経済性評価を行った。PV と BT の導入コスト注 (6)は、設 備ストと工事費などのその他の合計から、国からの ZEH 対する補助 金を考慮し、PV は 115 万円、 BT は $1 \mathrm{kWh}$ 当たり 2 万円を差し引い て算出した ${ }^{2122223) 。 E C ~ は 370 L ~ の も の を ~} 29$ 万円、180L のものを 25 万円とした注7)。SOFC は 2020 年度の標準価格より 100 万円 2425) と し、SOFC の補助ボイラーは 30 万円と設定した注 ${ }^{8)}$ 。耐用年数につ いては、PV は 20 年、BT と SOFC は 10 年、EC と補助ボイラーは 15 年と設定した ${ }^{25) 2627) 。 ~}$

電力の買電価格は家庭用電力小売料金水準の 24.0 円 $/ \mathrm{kW}^{28)}$ とし、 販売価格は東京電力の料金プランより、FIT 終了後における買取価 格 8.5 円/ $/ \mathrm{kW}$ とした。SOFC のガス購入費は東京ガスの「コージェ ネレーションパッケージ契約 29)」料金プランの 2019 年度平均より 106.3 円 $/ \mathrm{m}^{3}$ とし、SOFC からの発電電力の売電価格は併用発電時の 販売費より 24.0 円 $/ \mathrm{kW}^{30}$ 31) と設定した注9)。

図 7 にライフスタイルと設備容量による年間コスト注 10)を示す。 PV 発電の余剩電力のみを売る場合において、年間コストは単独発 電に比べ併用発電の方が、 2 人世帯条件で平均 2.1 万円、 4 人世帯条 件で平均 8.4 万円小さかった。一方、 $\mathrm{PV}+\mathrm{SOFC}$ 発電の余剩電力を 売る場合では、単独発電より併用発電の方が平均 16.0 万円、年間コ ストが小さかった。また、併用発電は PV 発電の余剩電力のみを売 ることより $\mathrm{PV}+\mathrm{SOFC}$ 発電両方の余剰電力を売ることで、平均 11.8 万円の年間コストが削減できることが確認された。

\section{5 まとめ}

本研究では、ライフスタイルによる太陽光発電と燃料電池の併用 発電の有効性検証を目的として、 $\mathrm{PV} \cdot \mathrm{SOFC} \cdot \mathrm{BT}$ などの家庭用分 散型エネルギーシステムのシミュレーションモデルを作成した。そ の後、ライフスタイルの違いがエネルギー消費量へ及ぼす影響の把 握や ZEH 達成の核となる設備機器容量や発電方法に着目し、複数 の生活パターンにおける設備導入効果及び経済性評価を行った。以 下に本報で得た知見を示す。

\section{(1) エネルギー評価}

売買電力量に関して、単独発電は 2 人世帯と 4 人世帯の両条件と もに PV 発電量の増加に伴い、売電量は増加し、買電量は減少した。 一方、併用発電では、 2 人世帯と 4 人世帯の両条件ともに PV 発電 量の増加に伴い、売電量は増加したが、買電量は発生しなかった。 自家消費率に関して、単独発電と併用発電ともに PV 容量の増加に 伴い、自家消費率が低下寸る傾向がみられた。一方、併用発電の場 合は PV と SOFC より発電するため、単独発電に比べ自家消費率が 低い結果となった。

\section{（2）－次エネルギー削減率及び ZEH 達成率の評価}

一次エネルギー削減率に関して、平均一次エネルギー削減量は単 独発電で $17 \%$ 、併用発電（PV の余剩電力のみ売る条件）で $37 \%$ 、 併用発電（PV と SOFC の余剩電量を売る条件）で $56 \%$ となり、併 用発電の場合は PV と SOFC の余剩電量を売ることで、一次エネル ギー削減率が平均 $19 \%$ 増加した。また、単独発電と併用発電ともに $\mathrm{PV}$ 容量の増加に伴い、ZEH 達成率は増加した。単独発電の場合は、 片働きの多消費型は PV7.5 kW、片働きの普通型は PV4.6kW 以上、 片働きの節約型は PV $3.0 \mathrm{~kW}$ 以上、共働きの普通型は PV $4.6 \mathrm{~kW}$ 以 上の条件で ZEH 達成率が $100 \%$ 以上なった。一方、併用発電にお いてはすべての条件で ZEH 達成率が 150～627\%で高い結果となっ た。以上より、単独発電の場合、片働き 2 人世帯において多消費型 は PV7.5kW+BT7.2kWh、普通型は PV6.0kW + BT7.2kWh、節約 型は PV $3.0 \mathrm{~kW}+\mathrm{BT} 7.2 \mathrm{kWh}$ 、共働き 2 人世帯の普通型は PV $4.6 \mathrm{~kW}$ $+\mathrm{BT} 7.2 \mathrm{kWh}$ 、片働きと共働きの 4 人世帯は PV7.5kW+BT7.2kWh の設備組み合わせが、適切である(ZEH 達成率 $100 \%$ 以上、自家消 費率が最も高い、売電量が買電量以上の条件を全て満たす）ことが 確認できた。また、併用発電の場合、すべてのライフスタイルにお いて PV $3.0 \mathrm{~kW} 、 S O F C 0.7 \mathrm{~kW} 、 \mathrm{BT} 7.2 \mathrm{kWh}$ の設備組み合わせが適切 であることが確認できた。

\section{(3) 経済性評価}

ライフスタイルによる適切な設備容量の組み合わせにおいて年 間コストを評価した。PV 発電の余剩電力のみを売る場合は単独発 電に比べ、併用発電の方が 2 人世帯条件で平均 2.1 万円、 4 人世帯 条件で平均 8.4 万円の年間コストが削減できた。また、PV と SOFC 発電の余剩電力を売る場合は単独発電より併用発電の方が約 11.8 
万円の年間コストが削減できた。

本研究では、単独発電と併用発電を導入する際に、ライフスタイ ルや生活パターンなどを考慮し、それぞれの発電方法に応じて適切 な設備容量の提案を行い、提案した設備容量の組み合わせに基づい て経済性評価を行った。その結果、単独発電より併用発電の方が $\mathrm{ZEH}$ 達成率や一次エネルギー削減率が高いことが確認された。また、 年間コストも併用発電の方が小さい結果となった。なお、本研究で は、BT の容量を $7.2 \mathrm{kWh}$ に固定しており、また PV と SOFC の設 備容量及び価格、系統との売電・買電価格などの設定に制限があっ た。BT の容量や SOFC の発電モードなどを考慮した、様々な設備 の組み合わせなどの考察、評価は今後の課題である。

\section{謝辞}

本研究は早稲田大学理工学術院総合研究所、スマート社会技術融合 研究機構のプロジェクトの一部である。

注

注1）「併用発電」は「W 発電」と呼ばれている。

注2）「SCHEDULE」はNHK 国民生活時間調査に基づいた空気調和・衛生工 学会のスケジュール作成ソフトである。

注3）自家消費率計算

【単独発電の場合】

自家消費率 $=(\mathrm{PV}$ から宅内人の電力量 $+\mathrm{PV}$ から BT への充電量 $) /(\mathrm{PV}$ 発電量 $) \times 100$

【併用発電の場合】

自家消費率 $=(\mathrm{PV}$ から宅内人の電力量 $+\mathrm{PV}$ から $\mathrm{BT}$ への充電量+ SOFC から宅内への電力量 + SOFC から BT への充電量) / ( PV 発電量 + SOFC 発電量 $) \times 100$

注4）一次エネルギー削減率計算

一次エネルギー削減率＝エネルギー消費削減量/基準エネルギー消費 量 $\times 100$

エネルギー消費削減量 $=$ (基準エネルギー消費量一平成 28 年省エネ基 準による暖房・冷房・換気・給湯・照明の基準エネルギー消費量の合 計） + (一太陽光発電などによる削減量十売電量 $)$

注5） ZEH 達成率

【単独発電の場合】

$\mathrm{ZEH}$ 達成率 $=\mathrm{PV}$ 発電量/（家電 + 冷暖房 + 給湯 $) \times 100$

【併用発電の場合】

$\mathrm{ZEH}$ 達成率 $=(\mathrm{PV}$ 発電量 $+\mathrm{SOFC}$ 発電量一ガス流量 $) /($ 家電 + 冷暖房 十給湯） $\times 100$

注6） PVと BT の導入コストは、実際に実験住宅へ導入した設備機器メーカ の 2020 年度版カタログを用いて算出した。

注7） EC において、2 人世帯は $180 \mathrm{~L}$ のもの、4 人世帯は $370 \mathrm{~L}$ のものとして、 各メーカの商品価格の平均料金と設定した。

注8） SOFC の補助ボイラーは高効率であるエコジョーズとし、各メーカの商 品価格の平均料金と設定した。

注9）本論文では、系統へ PV の余剩電力のみを売る場合と PV と SOFC の字 余剩電力を両方売る場合を想定して比較を行った。SOFC の買取料金を 選定は必ずしも一般的とは言えない。

注10）年間コスト算出式 ${ }^{32}$

【単独発電の場合、】

年間電気代 $=1$ 年間の買電料金 -1 年間の売電料金

年間コスト $=\mathrm{PV}$ 導入コスト/耐用年数 $+\mathrm{BT}$ 導入コスト $/$ 太陽年数 $+\mathrm{EC}$

導入コスト/而用年数 + 年間電気代

【併用発電の場合】

年間電気代 $=1$ 年間の買電料金 -1 年間の売電料金 -1 年間の SOFC 売 電料金

年間コスト $=\mathrm{PV}$ 導入コスト/耐用年数 $+\mathrm{BT}$ 導入コスト/太陽年数 + $\mathrm{SOFC}$ 導入コスト/耐用年数 + 補助ボイラー導入コスト/耐用年数 + 年間 電気代 + 年間ガス料金
参考文献

1) Ayane SHIBUTANI et al.: Influence of Energy Consumption Considering Life Patterns in Zero-Energy House, Summaries of Technical Papers of Annual Meeting, Architectural Institute of Japan, Environmental Engineering-II, pp. 917-918, 2015.7

渋谷ら : ゼロ・エネルギー住宅におけるライフスタイルがエネルギー 消費量に与える影響, 日本建築学会大会学術講演梗概集, 環境工学II, pp. 917-918, 2015. 7

2) Agency for Natural Resources and Energy: Trends in the introduction of renewable energy power sources, 2015

経済産業省資源エネルギー庁：再生可能エネルギー各電源の導入の動 向について, 2015

3) Yuji NAKATA : Smart Grid and Smart City to Achieve a Transition to a Lower Carbon Society, Institute of Electrical Engineers of Japan, pp. H1(10)-H1(13), 2012

中田祐司：低炭素社会を実現するスマートグリッドとスマートシティ， 電気学会全国大会, pp. H1(10)-H1(13), 2012

4) Agency for Natural Resources and Energy: ZEH roadmap follow-up committee, 2020. 2

経済産業省資源エネルギー庁 : 令和元年度 ZEH ロードマップフォロー アップ委員会とりまとめ, 2020. 2

5) Ministry of Land, Infrastructure, Transport and Tourism: Chapter 3 low carbon technology of building by fuel cells, Research report No. 45, pp. 162-241, 2014 国土交通省：国土技術政策総合研究所，第 3 章燃料電池等による建物 の低炭素化技術，研究報告第 45 号,pp. 162-241, 2014

6) Green post : Introducing the $\mathrm{W}$ power generation using fuel cells and solar power generation, Osaka gas, http://greenpost.way-

nifty.com/sinaken/2007/11/post 40fd.html (accessed 2019.11.7)

しなやかな技術研究会 : 関西初、家庭用燃料電池と太陽光発電を組み 合わせた「W（併用）発電システム」を導入し一般公開します，大阪 ガス, http://greenpost.way-nifty.com/sinaken/2007/11/post_40fd.html（参照 2019.11.7)

7) Kiyoshi WATANABE : Hydrogen Energy News, Hydrogen Energy Systems Society of Japan, Vol. 17, No. 3, pp. 83-90, 2010

渡辺潔 : 水素エネルギーニュース, 一般社団法人水素エネルギー協会, 第 17 巻, 第 3 号, pp. 83-90, 2010

8) Agency for Natural Resources and Energy: Definition of ZEH (revised edition) $<$ detached houses $>$, ZEH roadmap follow-up committee, 2019. 2 経済産業省資源エネルギ一庁：ZEH の定義（改定版）－戸建住宅＞， ZEH ロードマップ フォローアップ委員会, 2019.2

9) Tianshu XU et al.: Operation Method for Self-Consumption of Surplus Power Considering Thermal Comfort in Houses Part 1: Overview of Simulation and Validity Evaluation of the Model, Summaries of Technical Papers of Annual Meeting, Architectural Institute of Japan, Environmental Engineering-II, pp. 1195-1196, 2017. 7

徐ら：住宅における快適性を考慮した自立的運用に関寸る研究 その 1 : シミュレーション概要およびモデル妥当性検証, 日本建築学会大会学 術講演梗概集, 環境工学-II, pp. 1195-1196, 2017.7

10) Takeshi TAKENAKA et al.: Collaboration Control of Window and AirConditioning System in Consideration of Human Thermal Comfort and Energy Saving Part1: Detail about The Control System and Outline of The Target Housing, Summaries of Technical Papers of Annual Meeting, Architectural Institute of Japan, Environmental Engineering-II, pp. 159-160, 2014. 7 竹中ら: 熱的快適性・省エネルギー性を考慮した空システムとエアコン の協調制御 その 1: 制御システムと評価対象建物概要，日本建築学会大 会学術講演梗概集, 環境工学-II, pp. 159-160, 2014.7

11) Marina EBE et al.: Collaboration Control of Window System and Air Conditioner in Consideration of Human Thermal Comfort and Energy Saving Part2: A Comparison of Electric Power Consumption between Collaboration Control and Control of Only Air-Conditioning System, Summaries of Technical Papers of Annual Meeting, Architectural Institute of Japan, Environmental Engineering-II, pp. 161-162, 2014. 7

江部ら：熱的快適性・省エネルギー性を考慮した空システムとエアコン の協調制御 その 2: 協調制御とエアコン単体制御の電力消費量の比較, 日本建築学会大会学術講演梗概集, 環境工学-II, pp. 161-162, 2014.7

12) Koudai UMETANI: Optimum Management Method of Energy Creation Equipment of Zero-Energy House, Waseda university, Department of architecture, master's thesis, 2015

梅谷耕大 : ゼロ・エネルギーハウスにおける創蓄連携設備の最適制御 方法に関する研究, 早稲田大学建築学科修士論文, 2015 
13) Shohei NINO et al.: Evaluation on SOFC Installation with Consideration to energy Demand Variation, Journal of Air-conditioning and Sanitary Engineers of Japan, pp. 61-64, 2014

新野将平ら: エネルギー需要のばらつきが SOFC 導入効果に与える影 響, 空気調和・衛生工学大会学術講演論文集, pp. 61-64, 2014

14) Agency for Natural Resources and Energy: Energy saving performance catalog (2014 summer edition), 2014

経済産業省資源エネルギー庁 : 省エネ性能カタログ（2014 夏版）， 2014

15) Kanto Electrical Safety Services Foundation HP, https://www.kdh.or.jp/safe/energy_saving/estimation/rice_steamer.html (accessed 2019.11.7)

関東電気保安協会 HP,

https://www.kdh.or.jp/safe/energy saving/estimation/rice steamer.html (参 照 2019.11.7)

16) Ayane SHIBUTANI et al.: Influence of Energy Consumption Considering Life Patterns in Zero-Energy House, Journal of Air-conditioning and Sanitary Engineers of Japan, pp. 249-252, 2015

渋谷ら：ゼロ・エネルギー住宅における住まい方と温熱環境がエネル ギー消費量に与える影響, 空気調和・衛生工学会大会学術講演論文集, pp. 249-252, 2015

17) Broadcasting Culture Research Institute: 2015 Lifetime survey report, 2015 NHK 放送文化研究所 : 2015 年国民生活時間調查報告書, 2015

18) Agency for Natural Resources and Energy: Energy saving performance catalog (2016 summer edition), 2016

経済産業省資源エネルギー庁 : 省エネ性能カタログ（2016 夏版）， 2016

19) Hiroshi TAKATA et al.: Study and Estimation of the Performance of Hot Water Storage Tank System in House: Part 10 Analysis of Energy Consumption and Efficiency Performance on CO2 Heat Pump Water Heater Based on the Modeling of Hot Water Loads, Architectural Institute of Japan, Vol. 37,pp. 365-368, 2014

高田ら：住宅用貯湯式給湯システムの稼働実態とその評価に関する研 究 その 10 給湯負荷モードによるエネルギー消費量・機器効率の検 討, 日本建築学会中国支部研究報告集, 第 37 巻, pp. 365-368, 2014

20) Kazuyuki KOBAYASHI et al.: Evaluation energy saving by operating heatpump based water heater (Eco cute) on excessive PV power, Journal of Airconditioning and Sanitary Engineers of Japan, pp. 61-64, 2015

小林ら：HEMS 情報を活用したエコキュートの効率的な運転制御手 法の検討 太陽光余剰電力を活用したエコキュートの昼間炊きげによ る省エネルギー性向上, 空気調和・衛生工学大会学術講演論文集, pp. 61-64, 2015

21) Agency for Natural Resources and Energy: $34^{\text {th }}$ document of calculation committee for procurement price, 2017. 12 経済産業省資源エネルギー庁：第 34 回調達価格等算定委員会資料, 2017. 12

22) Rehome-navi : how to choose household storage battery, life, capacity and power generation type, https://rehome-navi.com/articles/624 (accessed 2020.8.30)

リショップナビ : 家庭用蓄電池選び方寿命/容量/発電タイプ, https://rehome-navi.com/articles/624（参照 2020.8.30）

23) Agency for Natural Resources and Energy: Policy trend for promoting ZEH and relevant budget plan in 2020, 2020. 3 経済産業省資源エネルギー庁：ZEH の不急促進に向けた政策動向と令 和 2 年度の関連予算案, 2020.3

24) NEDO : Fuel cells $\cdot$ hydrogen technology development roadmap, 2018 NEDO : 燃料電池・水素技術開発ロードマップ, 2018

25) Fuel cell commercialization conference of Japan (FCCJ) : Evaluation and issue sharing document of hydrogen $\cdot$ fuel cells project $\lceil$ SOFC present and challenges」, 2019.6

燃料電池実用化推進協議会 (FCCJ) : 水素・燃料電池プロジェクト評 価・課題共有ウィーク資料「SOFC の現在と課題」, 2019.6

26) National policy unit $: 2^{\text {nd }}$ cost verification committee $\lceil$ document $7-2$ about all cogeneration $\rfloor$,

https://www.cas.go.jp/jp/seisaku/npu/policy09/archive02_02.html (accessed 2019.11.6)

国家戦略室：第 2 回コスト等検証委員会「資料 7-2 コージェネレー ションの全諸元について」,

https://www.cas.go.jp/jp/seisaku/npu/policy09/archive02_02.html（参照 2019.11.6)
27) Manae INABA et.al: Equipment constitution and occupant behavior in a net zero energy house considering resilience during power outages, Architectural Institute of Japan, Journal of Environmental Engineering (Transactions of AIJ), Vol. 86, No. 779, pp. 111-120, 2021.1

稲葉愛永ら：停電時のレジリエンスを考慮したゼロ・エネルギー住宅 における設備構成と居住者行動の提案, 日本建築学会環境系論文集, 第 86 巻，第 779 号, pp. 111-120, 2021. 1

28) Agency for Natural Resources and Energy : Acceleration of effort to independence of renewable energy (about various independence models), 2018

経済産業省資源エネルギー庁：再生可能エネルギーの自立に向けた取 組の加速化（多様な自立モデルについて）, 2018

29) TOKYO GAS : Cogeneration package contract, 2019. 10 東京ガス：コージェネレーションパッケージ契約, 2019. 10

30) Solar support center : Trend of power selling price of solar power generation, 2012

ソーラーサポートセンター：太陽光発電の売電価格の推移, 2012

31) ENECHANGE : What is combined power generation?, https://enechange.jp/articles/double-power-generation (accessed 2019.11.6) エネチェンジ：創エネ機器を併用する「併用発電」とは?, https://enechange.jp/articles/double-power-generation（参照 2019.11.6）

32) Environmentally symbiotic housing promotion council : Calculation procedure fir primary energy consumption (document 1-9), 2016 環境共生住宅推進協議会 : 一次エネルギー消費量の算定要領（資料 1 9) , 2016 


\author{
Jungmin KIM*1, Shin-ichi TANABE*2 \\ ${ }^{1}$ Junior Researcher, Dept. of Architecture, Waseda University, Dr.Eng. \\ ${ }^{2}$ Prof., Dept. of Architecture, Waseda University, Dr.Eng.
}

Since the Great East Japan Earthquake, although it has been required to introduce renewable energy and save energy in houses, the supply and demand of electric power remains an important issue. This study's purpose is to verify the effectiveness of combined power generation using photovoltaic power generation (PV) and solid oxide fuel cells (SOFCs) by lifestyle. We created a simulation model for a household distributed energy system with PV, SOFC, and a storage battery (BT). Focusing on understanding the impact of different lifestyles on energy consumption and the equipment capacity and power generation method to achieve a zero energy house (ZEH), we evaluated the equipment introduction effect and economic efficiency in multiple life patterns.

The following observations are reported in this article:

1) With regard to the energy evaluation, in single power generation, which uses only PV power generation, as the amount of PV power generation increased, the amount of sales energy increased, and the amount of purchased energy decreased. On the other hand, in combined power generation, which uses PV and SOFC, the amount of sales energy increased, however, there was no amount of purchased energy. The self-consumption decreased with the increase in PV capacity in single power generation and combined power generation.

2) With regard to the evaluation of primary energy reduction rate and ZEH achievement ratio, the average primary energy reduction rate was $17 \%$ for single power generation, $37 \%$ for combined power generation (selling only PV surplus power), and 56\% for combined power generation (selling surplus power of PV and SOFC). By selling surplus power from the PV and SOFC, the primary energy reduction rate increased by $19 \%$ on average. In addition, the $\mathrm{ZEH}$ achievement ratio increased as the amount of PV power generation increased in single power generation and combined power generation.

3) With regard to the economic evaluation, the annual cost was evaluated in terms of the combination of equipment capacity by lifestyle. When selling only the PV surplus power, combined power generation reduced the annual cost by an approximately JPY 21,000 under two-person household condition and an approximately JPY 84,000 under four-person household condition compared to single power generation. When selling surplus power of PV and SOFC, combined power generation reduced the annual cost of approximately JPY 118,000 compared to single power generation.

In this study, when introducing single power generation and combined power generation, we propose appropriate equipment capacity according to each power method by lifestyle and evaluated the economic efficiency. The results confirmed that combined power generation has a higher primary energy reduction rate and ZEH achievement ratio than single power generation. Moreover, the annual cost of combined power generation was less than that of single power generation. However, in this study, we fixed the BT capacity at $7.2 \mathrm{kWh}$, and there were restrictions on the capacity and price of PV and SOFC, and the power price of selling and purchasing with the grid. The evaluation of equipment combination considering the BT capacity and power generation mode of SOFCs is a future task. 